\title{
DIE WET EN GELOOFSBELYDENIS
}

\author{
DR. D. J. BOOYSEN
}

\section{TER INLEIDING:}

Binne die raamwerk van die liturgie wat in gebruik is in die drie Afrikaanse Kerke, word die Wet en Geloofsbelydenis albei as elemente in die erediens aangetref. Dit is egter so dat dit verskillende elemente is en in die bespreking wat volg sal dit afsonderlik behandel word.

Gemeenskaplik het die twee elemente die feit dat die bepaalde plek in die liturgie wat deur hulle ingeneem moet word nie heeltemal duidelik is nie en by die nagaan van die verskillende ordes wat vir die erediens aangebied word, blyk dit ook duidelik dat die posisie nooit duidelik was nie.

Die klaarblyklike rede moet daarin gesoek word dat met die Reformasie gebreek word met soveel van die bestaande gebruike. Die versobering wat ingetree het op die breë vlak van die teologie het ook in die gewone orde van die erediens sy neerslag gevind. Die sentraalstelling van die prediking het ' $n$ verskraling in die orde van die erediens meegebring. LUTHER het in die verband dan ook volgens ENGELBRECHT gesê: „Die grootste en vernaamste stuk van alle erediens is om die Woord te leer en te preek. Dit is beter om liewer alles weg te laat as die Woord, en niks beters kan gedoen word nie, as die Woord." $(4,43)$. In die liturgie vind ons dan ook dat die verskillende elemente soos die Wet en die Geloofsbelydenis of geheel-en-al uitgelaat word, of voortdurend van plek verwissel.

Hierdie wisselvorme wat ons by die Reformatore aantref, moet cok daaraan toegeskryf word dat daar opnuut 'n soeke was na daardie liturgiese vorme waarin die beste uitdrukking gegee kan word aan die "reformatoriese herontdekking van die Evangeliewoord" $(4,48)$.

Ons moet ook onthou dat sovele van ons liturgiese gebruike 'n lang historiese aanloop het. Met die Reformasie is dit anders gesteld. Daar moet nou op nuwe wyse uitdrukking gegee word aan die "nuwe" wat herontdek is. Die gebruike van die Roomse Kerk is derhalwe nie klakkeloos nagevolg nie en is slegs daardie clemente tot leengoedere gemaak wat vereenselwig kon word met die Reformatoriese leer.

$\mathrm{Al}$ is dit so dat daar nie klaarheid in die Reformatoriese tydvak was oor die liturgiese elemente nie, bly dit nogtans die wegspringplek van die Protestantse, Calvinistiese liturgie en kan ons nie anders as om juis daar te gaan lig opsteek nie. Dit spreek vanself dat ons in die liturgie wat ons volg, primêr rekening sal 
hou met die voorskrifte van die Heilige Skrif en dat ons voorts cie historiese ontwikkeling nie kan negeer en die hede se vrae in die verband nie kan verontagsaam nie.

\section{DIE WET:}

Met die Wet as liturgiese moment bedoel ons in die eerste instansie die Dekaloog soos ons dit opgeteken vind in Exodus 20:1-17. Dit is ook die weergawe wat algemeen in gebruik is instansie die Dekaloog soos ons dit opgeteken vind in Exodus by die kerke, in ieder geval dan by geleentheid van die Sondagoggend se erediens. Natuurlik is die teks van Deuteronomium 5:6-21 ewe geskik vir gebruik tydens die erediens. Wat meer is, die feit dat daarin plek-plek ' $n$ ander nuanse aangetref word en verskil is in formulering, bring mee dat 'n gemeente met groter aandag luister na hierdie „ander" vorm.

Die samevatting van die Wet (Mattheüs 22:35-40 en paralelle) word in die meeste gemeentes as wisselvorm gebruik vir die Dekaloog, veral ook tydens die aanddienste. Juis omdat die samevatting sy plek vind in die Belydenisskrifte van die kerk, kan daarteen nie beswaar ingebring word nie.

In sekere kringe word daar selfs voorkeur gegee aan die samevatting van die Wet ,als wij bedenken dat dit woord van den Heiland is" $(7,99)$. Om aan hierdie gedeelte prioriteit te verleen omdat dit die woorde van Jesus is, klink 'n bietjie sentimenteel. Feit is dat dit ook nie so heel Nu-testamenties is nie soos dit baie duidelik blyk uit Deut. 6:5 en Lev. 19:18. Dit wil nou nie sê dat ons afwysend staan teenoor die samevatting nie, maar dit sal heel goed as wisselvorm benut kan word.

LEKKERKERKER betoog dat die Dienaar van die Woord nie uitsluitend aan die Tien Gebooie gebonde is nie en dat ander Skriflesing uit die Ou Testament of uit die Briewe of die Evangelies ook die karakter van die gebod van die Here dra $(13,72)$. Hierteenoor behoort ons myns insiens tog standpunt in te neem. Alhoewel die verskillende gedeeltes die karakter dra van die gebod van die Here, kom dit in die besondere wyse na vore i.ı die Dekaloog. Nêrens elders in die Skrif word dit so omvattend volledig, duidelik gestel as juis in die Dekaloog nie: Wat God van ons wil en vra word daar onomwonde gesê. God se aanspraak op sy verbondskinders moet by die aanhoor van die Wet eerbiedig bely en gehoorsaam word.

As daar behoefte is aan wissenvorme vir die Wet, dan bied die variante daardie nodige wisselvorme en is dit nie nodig om 
na ander gedeeltes te gaan nie. Hierdie ander vorme is trouens nie vollediger as die Dekaloog nie, inteendeel, bepaalde gedeeltes is verswyg, en as samevatting kan dit ook nie gestel word teenoor die bondige, maar volledige weergawe van Matt. 22 nie.

Ons kan dit dus samevattend so stel dat as liturgiese moment die Dekaloog (Ex. 20, Deut. 5) gebruik behoort te word of as 'n samevatting voorgehou moet word, dan is Matt. 22 (of die paralelle daarvan) voldoende.

Die volgende aspek waaraan ons aandag moet gee is die vraag of die Wet wel as liturgiese moment in die erediens moet dien. In die verband kan ons baie kortliks aandag gee aan die feit dat dit inderwaarheid ' $n$ vereiste is.

Kerklike usansie is in baie gevalle deurslaggewend en so sal dit in die geval ook wees. Van meet af aan is die Vadere van mening gewees dat die Wet as selfstandige gestalte in die erediens plek verdien en is dit alleen by wyse van uitsondering nagelaat.

Hierteenoor moet gestel word dat dit in ieder geval die bedoeling was, dat die Wet ten minste een keer per Sondag plek sal kry in die liturgie van die erediens. Die Sinode van Dordt 1574 het dan bepaal dat die Geloofsbelydenis soggens en die Wet saans plek in die erediens sal kry $(11,213)$. Hierby sluit KUYPER aan en bied as motivering aan „Als de geloovigen tweemaal op elken Zondag saamvergaderen moeten deze beide diensten als èèn geheel en in ordelijk verband worden genomen" $(11,209)$.

Met hierdie opvatting kan ons vandag nie meer saamstem nie. Die twee eredienste wat per Sondag gehou word, is nie een geheel nie. Elke erediens is n' selfstandige erediens en die liturgiese elemente moet elke keer weer tot hulle reg kom in die erediens. Dit is ' $n$ verskraling van die erediens as daar na willekeur van die momente uitgelaat word. Wat meer is, dit is vandag in elk geval nie meer so vanselfsprekend dat die mense wat die een erediens bywoon ook die tweede erediens sal bywoon nie. Dit is ook so dat praktiese oorweginge meebring dat dit onmoontlik is vir 'n groot gedeelte van die lidmate van die kerk om twee eredienste per Sondag by te woon. Die enigste oplossing is daarom dat die Wet in elk geval in alle eredienste as liturgiese element gehandhaaf sal word.

Daar sal seker verskil van mening bestaan of die Wet by alle dienste wat in die kerk gehou word tot sy reg sal kom. Veral kan gedink word aan geleenthede soos die bevestiging van huwelike en begrafnisdienste. Skrywer is van mening dat die 
Wet ook in sulke gevalle as liturgiese moment gehandhaaf moet word. Hierdie geleenthede is eredienste en wat vir die een erediens geld, geld mutatis mutandis ook vir die ander. Ons moet ook voorts daarmee rekening hou dat dit juis geleenthede is waar talle buitekerklikes, randkerklikes en dergelike mense in die erediens kom. Hier moet die Wet van God duidelik weerklink!

Ten opsigte van die vraag of die Wet as liturgiese moment plek verdien kan ons voorts ook nog daarop wys dat dit eintlik as vanselfsprekend aanvaar word. Kort en kragtig stel KUYPER dit dan ook: „Dat ze in den Eredienst behoort te zijn opgenomen, is buiten kijf" $(11,209)$. Dit is voorts ook so dat dit in die huidige bedeling ook eintlik nie bevraagteken word nie. Dit is 'n gebruik wat diep gewortel is in die liturgie.

Dit is ook nog opvallend dat in die oorgrote meerderheid van ordes vir die erediens daar van meet af aan plek gegee word aan die Wet. ACHELIS is die mening toegedaan dat die Wet sy plek in die liturgie te danke het aan CALVYN. $(1,121)$. Hierdie mening word onderskryf deur KUYPER $(9,213)$. Dit is ook so dat CALVYN plek gee aan die Dekaloog in die Straatburgse ritus $(19,67)$ maar in die periode daarna sien hy maklik af van die element $(19,73)$. Dit word vandag ook betwyfel of die stelling van ACHELIS en KUYPER korrek is, want LEKKERKERKER wys juis daarop dat die Bazelse priester, Ulrich Surgant, 'n handleiding in 1502 uitgegee het, waarin hy aandag gee aan die preek, gebed, die Onse Vader, die tien gebooie ens. $(13,68)$. Hoe dit ookal sy, feit is dat die Wet as liturgiese element nie vreemd is aan CALVYN nie. Ook FAREL gee plek aan die Wet in die orde wat hy opgestel het vir die Sondagoggend se erediens. $(19,73)$.

Dit is nie net die skrywers uit die periode van die Reformasie wat aan die Wet plek gee in die orde van die erediens nie. Ook in hierdie eeu en selfs in die jongste jare het dit so gebeur. Om willekeurig keuses te maak kan verwys word na VAN DER LEEUW, (17, 166); GOLTERMAN, $(6,136 ; 5,187)$; JONKER $(9,82)$ en is dit ook Sinodaal bepaal $(15,12 ; 2, D 6)$.

Ons kan uit die voorgaande derhalwe tot die gevolgtrekking kom dat die Wet sedert (en selfs vòòr) die Reformasie wesenlike element van die orde van die erediens was en tans nog is en behoort te wees. Hiermee saam kan dan ook gestel word dat dit 'n element is wat in elke erediens sy plek moet kry.

Wanneer ons die juiste plek wil bepaal, moet ons ook rekening hou met die historiese ontwikkeling. Ons aandag word gevra vir Straatsburg. In die geskiedenis van die liturgie neem dit ' $n$ be- 
sondere plek in. Hier was die trefpunt van LUTHER, BUCER en CALVYN. $(17,147)$. Vir ons is dit van besondere belang omdat juis hier by die Franse liturgie van Straatsburg ,en nieuw element word toegevoegd" $(17,148)$ en dit is die lees van die Wet van die Here. VALERANDUS POLLANUS het 'n orde van die erediens vir die Franse in Engeland uitgegee 1551, waarin ons 'n goeie oorsig kry van die Straatburgse orde. Hiervolgens word die Wet gelees voor die Skriflesing en die prediking. Die man wat baie gedoen het vir hervormings op liturgiese gebied was BUCER. Dit spreek vanself dat CALVYN dan hier ook grootliks beinvloed is gedurende sy verblyf te Straatsburg. Die opvallende is dat CALVYN na aanleiding van wat hy in Straatsburg aantref die Dekaloog plek gee in sy liturgie en wel ook voor die Skriflesing en die prediking. Hy laat dit sing. $(19,67)$. Gaan ons 'n paar jaar verder terug in die geskiedenis vind ons 'n geskrif wat toegeskryf word aan FAREL 1533. Hy was ook by Straatsburg gewees maar in die liturgie waarvan hy voorstander is, vind 'n geweldige versobering plaas en dit word selfs as verarm getipeer. $(19,74)$. Die opvallende is die behoud van die Wet en wel weer na die prediking.

In 1542 verskyn 'n hersiening van die orde van Straatsburg van CALVYN waar die eienaardige opgemerk word: , . . . het wegvallen van de absolutie en van de gezongen Wet des Heren". $(19,73)$.

JOHANNES A LASCO wat die liturgie opgestel het vir die vlugteling-gemeente in Londen gee plek aan die Wet van die Here na die prediking. $(17,152)$. Ons tref ook dieselfde aan by MARTIN MICRON. $(9,127)$. Die Sinode van Dordrecht 1574 het egter weer anders bepaal. PETRUS DATHENUS het hier groot invloed uitgeoefen en ons vind dat die Calvinistiese kerke in navolging van die Sinode en uitbreiding van die besluite, die Dekaloog heel aan die begin van die diens geplaas het, pas na die eerste lied van die gemeente. Die Wetlesing is soms beant. woord met 'n lied. $(6,62)$.

Ons kan die voorgaande dus konkluderend so saamvat dat daar genoegsame getuienis is om aan die Wet plek te gee in die erediens. In die oorgrote meerderheid van gevalle het die Reformatore gebruik gemaak van die Dekaloog. Dit is ook duidelik dat in die meerderheid van gevalle plek gegee word aan die Dekaloog aan die begin van die erediens, of te wel voor die Skriflesing en die prediking plaasvind. 'n Ander aspek waarop ons moet let, is die feit dat in die meeste gevalle die Wet gelees is; by wyse van uitsondering tref ons die metriese sing daarvan aan en dit is ook beantwoord met 'n lied van die gemeente. 
Dit is ook ewe duidelik dat ons nog nie klaarheid het oor die plek van die Wet nie. Klaarblyklik sal dit weer afhang van ons siening van die Wet.

Volg ons in die spore van die Heidelberge Kategismus waar die Wet sy plek kry in die derde gedeelte, en wel dìe deel wat handel oor die dankbaarheid, lyk dit na 'n oplossing. As ons dit in aanmerking neem, kan ons die vreugde van LEKKERKERKER begryp as hy verklaar: „Daarbij is het bijzonder bevrijdend om met Calvijn het spreken ... van de Tien Geboden te verstaan als een Ere zij God in den hoge". $(13,72)$. Die posisie van die Wet in die Heidelbergse Kategismus, as stuk van die dankbaarheid bring ook mee dat deur talle voorkeur gegee word aan die Wet se posisie na die prediking. So is dit met VAN DER LEEUW $(17,166)$, en met KUYPER. Laasgenoemde sien die Wet as reël van dankbaarheid vir die praktyk van die lewe "... na die predikatie, als ze het kerkgebouw verlaten" $(11,215)$. Hierby sluit VAN DER WERF $(20,44)$ aan as hy sy voorkeur te kenne gee aan die Wet aan die einde van die erediens ,opdat men de geboden Gods mee zou nemen het leven in. Een op zichzelf zeer zinvol gebruik."

Klaarblyklik is dit ook die rede waarom die Wet opgeneem is in die Formulier om die Heilige Nagmaal te hou. Dit beteken dus dat die Vadere dit so verkies dat die Wet na die prediking in die gemeente gelees moet word.

Ons kan egter ook die Wet plaas voor die prediking. Motivering moet gesoek word in die uitspraak van Galate 3:24: „Die Wet was dus ons tugmeester na Christus toe, sodat ons geregverdig kan word uit die geloof". As ons die Wet sien as tugmeester dan wil dit impliseer dat God reg op ons het $(18,322$; 17, 167). ACHELIS bied 'n verklaring vir die goeie reg om die Wet voorop te plaas. Hy betoog dat die bedoeling dan is, dat die gemeente wat straks in gebed voor God gestel word, onder die indruk gebring word van die oortredinge, sodat die gemeente tot die regte skuldbelydenis gebring sal word. Die gemeente is geroepe om heilig voor God te wandel en die Wet as tugmeester bring mee dat die gemeente homself sal ken $(1,122)$. Vir hierdie standpunt word ook teruggegryp na die Heidelbergse Kategismus waar ons in die tweede Sondagsafdeling alreeds leer dat ons ons ellende ken uit die Wet van God. GOLTERMAN opper beswaar teen hierdie opvatting en noem dit 'n "legalistische" opvatting (6, 2v.v.).

'n Ander faktor wat ons in die verband nie moet vergeet nie noem PAQUIER die pedagogiese karakter van die erediens $(16,169)$. Nou noem LEKKERKERKER juis die feit dat die Wet 
tot die onderrig behoort $(13,63)$. As ons nou voorts in aanmerking neem dat die eucharistiese element sterk op die voorgrond was in die ritus soos dit voorheen bekend was $(3,56)$ dan kom die karakter sterk na vore. Dit omdat diegene wat nog nie belydende lidmate was nie, die samekoms moes verlaat voordat die gemeente sy Nagmaal vier. Die eerste gedeelte van die erediens was derhalwe bedoel om te onderrig. Met die Wet dus voorop in die erediens leer die gemeente sy ellende reg ken.

Kerklike praktyk het vandag meegebring dat die Wet in die eerste gedeelte van die erediens geplaas word. Die kerke verstaan dit dus as tugmeester na Christus. In talle gemeentes word ook 'n lied gesing wat as spontane lied bekend is. Hierdie lied is in werklikheid verlenging van die verkondiging. $(10,246)$

As ons nou enige gevolgtrekkings moet maak, dan wil dit voorkom asof daar genoegsame rede is om die Wet of voor die Skriflesing en prediking te plaas of om dit na die prediking plek te gee in die liturgie. Die feit dat die kerklike praktyk die keuse uitgewys het, moet 'n mens dalk daarmee volstaan.

Daar is nog een aspek wat net genoem moet word: In die Nederduitsch Hervormde Kerk van Afrika is dit gebruiklik dat 'n ouderling die Wet voorlees aan die gemeente. Elders word gehandel oor die voorleser, daarom gee ons nie hier aandag daaraan nie. KRET het daarop gewys dat dit so kan gebeur $(10,245)$ en miskien moet dit gesien word as deel van die regerende taak van die ouderling wat opnuut aan die gemeente die Wet voorhou as tugmeester.

\section{GEVOLGTREKKINGS.}

Die Wet en wel die Dekaloog of die samevatting daarvan moet deel uitmaak van die liturgie van die Sondagse eredienste.

Die Wet moet desl uitmaak van die liturgie van alle eredienste. Daar is geen gronde om dit na willekeur uit te laat nie.

Die posisie in die orde van die diens kan nie sondermeer vasgepen word nie.

\section{DIE GELOOFSBELYDENIS.}

Die vorm waarin die gemeente sy geloof bely, kan alleenlik die wees soos ons dit ken in die Twaalf Artikels van ons Christelike geloof, of die Geloofsbelydenis van Nicea - Konstantinopel of in die laaste instansie die Geloofsbelydenis genoem na Athanasius. 
Aangesien dit op die weg van die Dogmengeskiedenis lê om die ontwikkeling van die geloofsbelydenis te beskrywe, laat ons dit daar.

In kort kan ons net daarop wys dat enkele plekke in die Nuwe Testament laat vermoed dat die geloofsbelydenis in noue samehang met die Doop vroeg reeds plek gekry het, (Hand. 8:37; 1 Pet. 3:18-22; Hebr. 10:23 v.v.) so betoog VAN DER SCHOOT (19, 11) en GOLTERMAN $(6,29)$. VON HARNACK wys ook duidelik dat die Twaalf Artikels soos ons dit ken herleibaar is na die vrae wat gestel is by die doop ongeveer 150 v.C. $(21,145)$ MARTIN toon ook aan dat die doopvrae behoue gebly het in die geskrifte van Justinus die Martelaar (ongeveer 100-165 n.C.), Irenaeus 130 -200 n.C. en Hippolitus van Rome ongeveer 215 n.C. en dat dit juis vir ons behoue gebly het in die Apostolicum $(14,61)$.

\section{VERDIEN DIT PLEK IN DIE ORDE VAN DIE EREDIENS?}

Dit is wel so dat die element nie baie oud is nie. Aan die anderkant was dit reeds in swang voor die Reformasie aangebreek het. Dit is derhalwe nie 'n produk van die Reformasie nie. In die vierde eeu het die Geloofsbelydenis van Nicea-Konstantinopel p!ek gekry in Antiochië en dit is eers in die elfde eeu opgeneem deur Rome. Ouderdom alleen bepaal egter nie die waarde van 'n element nie en daar kan goeie redes wees waarom die Geloofsbelydenis aanspraak kan maak op 'n plek in die orde van die erediens. PAQUIER stel dit so: „Its use may be justified however, for some good reasons: if the congregation comes together to be rourished and built up in the faith, it is a normal thing to confess its faith in unison. When the church is under the cross, when it is fighting against the vexation and persecution of a totalitarian civil power, then the confession of faith said by the whole congregation has such force and impact that all theological or liturgical justification of this usage becomes superfluous. $(16,174)$.

As ons dan in aanmerking neem dat daar genoegsame gronde in die skrif is soos VAN DER SCHOOT en GOLTERMAN aangetoon het, dan hoef ons nie te twyfel of dit plek verdien nie.

As ons nou na die periode van die Reformasie kyk, dan sien ons dat in die talle ordes wat verskyn het, daar bykans altyd plek gegee is aan die Geloofsbelydenis. Die voor die hand lig. gende rede moet ons sien in die gebruik daarvan by die Roomse Kerk. Die Reformasie het nie sondermeer bateken dat alles oorboord gegooi is nie. Wat as sinvol, Bybelsgefundeerd geag is, is ook wel weer geimplimenteer, al het dit met die nodige aanpassing gepaard gegaan. 
Dit is tog goed om die funksie wat dit beklee het by Rome net te betrag. Sedert 1014 het dit vaste plek gekry in die orde van die Roomse mis. Dit word uitgespreek in die oorgang van die leerdiens na die mis van die gelowige d.w.s. van die diens van die woord na die viering van die Nagmaal. In 1591 is opnuut weer besluit dat die credo na die redevoering, dit is die prediking moet plaasvind. Dit dien dus uitsluitlik as oorgangsfase. $(13,93)$.

\section{DIE REFORMASIE.}

LUTHER het in die Deutsche Messe 1525 plek gegee aan die credo pas na die lees uit die Evangelie. Hy laat dit sing in die Duitse taal: Wir glauben all an einen Gott, dit is dus die Geloofsbelydenis van Nicea-Konstantinopel wat hy gebruik. $(19,59 ; 13$, 93).

ZWINGLI het in 1525 sy orde opgestel in sy „Action oder Bruch des Nachtmals" waarin hy netsoos Luther die credo plaas na die lees van die Evangelie. LEKKERKERKER gee te kenne dat ZWINGLI hier die Apostolicum gebruik en dat dit afwisselend gesing word deur die manne en vroue van die gemeente $(13,93)$. Hierteenoor merk VAN DER SCHOOT egter op: Muziek (incluis kerkgezang) werd radicaal afgewezen $(19,63)$. VAN DER WERF is dit eens met Van die Schoot $(20,38)$. In ieder geval of dit gesing is of nie, die plek daarvan is tog duidelik. BUCER laat die Apostoliese Geloofsbelydenis na die prediking sing $(13,94)$. Ons het reeds gewys op die belangrikheid van Straatsburg. Hier is dit volgens ROUSSEL so ingerig dat die hele gemeente na die prediking die credo sing. Die Apostolicum is ook hier in gebruik $(19,66)$. CALVYN het in aansluiting by die orde vir die erediens van Straatsburg die Apostolicum laat sing na die prediking, of meer korrek na die groet-gebed terwyl die elemente vir die viering van die Nagmaal voorberei word. Hy stel die Geloofsbelydenis derhalwe in die onmiddellike nabyheid van die toetrede tot die tafel van die Here. $(13,94 ; 19,68$. By MICRON vind ons dit so dat die credo bykans aan die einde van die erediens geplaas word, net voor die gebed vir alle nood en die psalmgesang. $(20,43)$. Die opvallende is dat MICRON by die middagdiens al die elemente na die prediking uitlaat, dus ook die credo $(20,43)$. Die Sinode van Dordrecht 1574 laat 'n nuwe klank hoor as die gebed na die preek uitloop in die credo. $(20,44)$.

Die Reformatore, by name ZWINGLI, CALVYN en BUCER het voorkeur verleen aan die vorm van die Twaalf Artikels omdat dit eenvoudiger is as die Nicea-Konstantinopel. CALVYN het hom hieroor uitgelaat en beweer dat die Niceense Geloofsbelydenis eintlik in woorde oorlaai is. $(13,94)$. 
Uit die voorgaande kan ons enkele gevolgtrekkings maak: Die Reformatore het dit klaarblyklik noodsaaklik geag dat daar in die orde van die erediens plek ingeruim moet word vir die credo. Verskillende vorme van die credo is gebruik, met duidelike voorkeur aan die Apostolicum deur byvoorbeeld CALVYN. In die meeste gevalle word die credo na die prediking geplaas, maar die posisie is ook nie vasgestel nie. Dit varieer dikwels. Dit is ook opvallend dat die credo dikwels gesing is deur die gemeente.

\section{DIE VORM VAN DIE CREDO.}

Hierna is alreeds in die voorgaande verwys. Die Apostolicum geniet blykbaar voorkeur. Die Geloofsbelydenis genoem na Athanasius word as te lank bestempel vir gebruik by die gewone erediens. $(6,143)$. PAQUIER wys egter op 'n ander gevaar. The weekly use of the creed may become boring and vain repetition. ... Therefore, some variety is commendable: one should turn on one occasion to the Apostles' Creed, on another to the Nicene, ... $(16,176)$.

Ons moet tog daarop wys dat die afwisselende gebruik van die verskillende geloofsbelydenisse 'n absolute noodsaaklikheid is. Die rede is voor die hand liggend: Dit is goed moontlik om die Apostolicum te bely maar dieselfde persoon kan miskien beswaar hê om die Godheid van Christus te bely soos die NiceaKonstantinopel dit wel doen. Hierdie ongerymdhede kan op die wyse opgeklaar word.

\section{DIE PLEK VAN DIE CREDO.}

Hier het ons weer met 'n probleem te make. 'n Groot verskeidenheid in die plek van die credo kom aan die lig by die nagaan van die verskillende feite. Dit kan na die gelese Evangelie, na die gepredikte Evangelie, voorafgaande aan die gebede vir alle nood van die Christendom, of daaropvolgend geplaas word. $(13,94)$. KUYPER het die sinvolle opmerking gemaak dat die belydenis van die geloof deur die gemeente die slotakkoord is, dit is die weerklank ,op het gepredikte Woord, het ,Amen wij geloven' dat de gemeente na het beluisteren van Gods Evangelie voelt oprijzen in haar hart en uitspreekt met haar lippen. Want het geloof is uit het gehoor en het gehoor uit het gepredikte Woord." $(11,214)$.

VAN DER LEEUW huldig dieselfde mening. Die belydenis kan eers na die prediking plaasvind omdat alleenlik gelowiges waarlik hulle geloof kan bely. $(17,175)$. Die kommissie aan wie die taak opgedra was om die Diensboek vir die Nederlandse Her- 
vormde Kerk op te stel, het die credo geplaas onmiddellik na die prediking. Dit is gedoen om die credo te laat dien as samevatting van die gepredikte Evangelie. $(13,95)$.

In 'n voetnota in die werk van LEKKERKERKER word verwys na 'n aanhaling uit ZWINGLI se "De canone missae epichiresis" van 1523 waarin hy die credo 'n belydenis noem van wat tevore gehoor is en die uitlegging van die Evangelie $(13,95)$. Hierdie kommissie het egter ook ruimte gelaat vir afwisseling want in die Orde 111 word die credo geplaas na die genadeverkondiging en voor die Wet. Klaarblyklik is dit gedoen omdat daar nie oorgegaan word tot die viering van die Nagmaal nie.

By die erediens wat as leerdiens geld gee hulle voorkeur aan die gesproke geloofsbelydenis bo die belydenis wat gesing word. Die Dienaar van die Woord "onderwijst en zegt in dit kader het Geloof." $(13,96)$. Die Sinode van die Kerk het egter in die verband die aanbevelings van die kommissie verwerp en gee plek aan die credo na die genadeverkondiging. Hier word dus vaste plek gegee aan die credo $(11,96)$. Die Algemene Kerkvergadering van die Nederduitsche Hervormde Kerk van Afrika van 1967 het die vaste plek van die credo gegee na die Wetlesing en voor die Skriflesing. (2, D.8).

Dit wil dus voorkom asof die histories-verantwoorde plek van die credo na die prediking sal wees. Dit geld dan vir sowel die Nagmaalsviering as die gewone Sondagoggend se erediens. Voorkeur word in al drie die kerke gegee aan die credo voor selfs die Skriflesing. Kerklike praktyk het ook hieraan voorkeur gegee. Dit is miskien nie so 'n goeie gebruik in die kerk nie.

Ons het ten opsigte van die Wet dit gestel dat daar by elke erediens plek gegee moet word aan die lees van die Wet. Dieselfde argumente wat daar aangevoer word, geld ook vir die geloofsbelydenis. Hieroor is daar verskil van mening. Daar is byvoorbeeld Sinodale bepalings dat dit nie twee keer per Sondag hoef te gebeur nie $(8,118)$. Hieroor verskil ons. KUYPER voer aan dat dit nie moet gebeur nie. „Dit ware een omslachtigheid die zou afmatten". (11, 259). Nou, dit kan nie die oorwegende rede daarteen wees nie! Waar die gelowiges van God bymekaar gekom het, moet daar geleentheid wees sodat daar saam met die Kerk van alle eeue bely sal word. Dit is ongehoord dat die versamelde gelowiges nie hulle geloof sal bely nie.

Ons het nog een vraag te behandel en dit is die manier waarop die gemeente sy geloof sal bely. 
VAN DER LEEUW wys daarop dat die gemeente dit staande sal doen as teken van bereidheid tot die diens van God. $(17,176)$. Die huidige kerklike praktyk is hiermee in ooreenstemming en daarom hoef ons nie verder hieroor te betoog nie.

Die ander vraag wat in die verband na vore kom is alreeds aangesny. Moet die Geloofbelydenis voorgelees word of nie. Uit clie voorgaande het ons gesien dat dit ook deur die gemeente gesing is. KUYPER het reeds daarop gewys dat daar drie moontlikhede is:

a. Die gemcente spreek deur een van die lede van die gemeente.

b. Die hele gemeente kan spreek.

c. Die hele gemeente kan sing. (11, 260-).

Hyself gee voorkeur daaraan dat die hele gemeente dit saam sal doen en wel op die patroon van die Engelse gebruik deur saam te spreek. As alternatief stel hy die moontlikheid dat dit resitatief gesing kan word. $(11,262)$. GOLTERMAN verleen ook voorkeur daaraan dat die gemeente in sy geheel die Geloofsbelydenis sal uitspreek. $(6,144)$, en VAN DER LEEUW betoog dat die belydenis bely en nie aangehoor moet word nie. $(17,176)$. Die voorganger behoort dit duidelik en stadig voor te sê en die gemeente spreek dan agterna. ACHELIS daarenteen, betoog op sy beurt weer dat die liturg as mond van die gemeente die Geloofsbelydenis uitspreek by die begin van die godsdiensoefening om daarmee te kenne te gee dat hier nie 'n sekere godsdienstige byeenkoms is nie, maar 'n samesyn van die gemeente wat op hierdie geloofsgrond staan sodat al wat in die lied, gebed gespreek word en uit die mond van die prediker gehoor word, beskou moet word asof deur die gemeente van Christus gespreek is $(1,123)$. Elke individuele spreek nie, maar die gemeente in sy geheel spreek by monde van die voorganger. JONKER sien die credo as 'n samevatting van die Evangelie. Dit het dus 'n kategetiese funksie sodat dit na die Skriflesing deur die Dienaar van die Woord as samevatting van die hemelse leer wordt voorgelezen! $(9,132)$.

Uit die geskiedenis leer ons ook dat die credo as 'n gebed gesien is. AUGUSTINUS het die gelowiges aangemoedig om die credo daagliks te bid en veral die Roomse liturgiste lê nadruk daarop dat die credo gebid kan word. Die Dordtse Sinode van 1574 laat die tweede gebed, dit wil sê na die prediking, uitloop op die credo. $(13,94)$.

Die drie Afrikaanse Kerke volg in die verband verskillende gebruike. Elkeen kan met goeie reg teruggryp op die uitsprake van die voorgangers. Ons laat dit dus daar. Die lied wat die 
gemeente aanhef na die Geloofsbelydenis betrek in ieder geval die hele gemeente sodat dit waarskynlik ook verlengstuk van die Geloofsbelydenis is en dan kan dit net sowel deur die voorganger uitgespreek word.

Omdat hierdie betoog alleen as inleidende besinning wil dien, sal die finale gevolgtrekkings later gemaak moet word. Dit geld vir die plek van sowel die Wet as die Geloofsbelydenis. Een ding is egter duidelik en dit is dat ons hier met twee uiters belangrike elemente te make het, wat met reg aanspraak maak op deeglike en verantwoordelike besinning. 